\title{
Strategi Pengembangan Objek Wisata Danau Mesjid Sebagai Objek Wisata Unggulan di Kabupaten Kuantan Singingi
}

\author{
RINI YULIARTI \\ J1. Pattimura No. 54 Gobah Pekanbaru - Riau \\ Telp. : 0761 - 35531 \\ Email: stipar_apeph@yahoo.com
}

\begin{abstract}
Koto Mesjid Lake Kari potential as a tourist attraction is very large. Then there is still the need for a strategy that can really be to develop a tourist attraction that is better known by the public. The method used is a method desktriptif. Results showed that the Office of Tourism Youth and Sports Kuantan Singingi as business work has made strides in developing Attractions Lake Mosque. They tried to run strategies are considered able to develop attractions Lake Mosque. Strategies undertaken by the Department of Tourism Youth and Sports such as: Boosting promotional activities, Doing Making regulation About Tourism Kuantan Singingi, Facilities Development and Infrastructure, Building Supporting Facilities, Attractions Lake Mosque Koto Kari has the potential object of sufficient good of the means as well as supporting infrastructure. This potential is supported by natural circumstances.
\end{abstract}

Keywords: Strategy, Development attractions

Indonesia adalah negara yang kaya dengan ragam sumber daya alam, lingkungan dan budaya. Indonesia juga sangat berpotensi dalam mengembangkan pariwisata sebagai sektor andalan masa depan. Kekayaan potensi kepariwisataan Indonesia tidak saja mencakup unsur keindahan alam, keaslian, kelangkaan dan keutuhan, juga termasuk semua kekayaan budaya, flora, fauna, ekosistem dan kondisi alam, yang jika dikelola dan dikembangkan secara profesional akan dapat menempatkan Indonesia sebagai negara tujuan utama wisatawan dunia.

Pariwisata merupakan salah satu sektor yang sangat penting dalam pembangunan ekonomi khususnya ekonomi kerakyatan. Seiring dengan perubahan global, paradigma pariwisata Indonesia sudah memperlihatkan perubahan yang signifikan. Pada masa lalu spektrum pembangunan pariwisata lebih diorientasikan pada beberapa kawasan penting saja, sementara dilihat dari kecendrungan perubahan pasar global pariwisata sudah sangat diminati oleh pengusaha lokal dan juga mancanegara yang turut menginvestasikan modalnya disektor pariwisata yang tersebar diseluruh wilayah Indonesia.

Pembangunan pariwisata pada hakikatnya merupakan upaya untuk mengembangkan dan memanfaatkan potensi wisata yang dimiliki daerah dalam mewujudkan kekayaan alam yang indah dan keanekaragaman flora dan fauna, tradisi dan seni budaya serta peningalan sejarah purbakala. Upaya ini harus sejalan dengan pengembangan jasa dan sarana pariwisata agar memperoleh hasil yang optimal. Menurut Undang Undang Republik Indonesia Nomor 10, Tahun 2009 tentang kepariwisataan digariskan bahwa pembangunan pariwisata perlu ditingkatkan untuk memperluas kesempatan kerja dan kesempatan berusaha, meningkatkan penerimaan devisa serta memperkenalkan alam kebudayaan bangsa Indonesia. Dalam menghadapi perubahan global dan penguatan hak pribadi masyarakat untuk menikmati waktu luang dengan berwisata, perlu dilakukan pembangunan kepariwisataan yang tertumpu pada keanekaragaman, keunikan dan kekhasan bangsa dengan tetap menempatkan kebhinekaan sebagai suatu yang hakiki 
dalam bingkai Negara Kesatuan Republik Indonesia.

Sebagai salah satu propinsi di Indonesia, Riau mempunyai letak yang strategis yang berbatasan langsung dengan dua daerah tujuan wisata, yaitu Sumatera Barat dan Sumatera Utara, juga berbatasan langsung dengan dua negara tetangga, yaitu Malaysia dan Singapura yang merupakan negara potensial bagi pemasaran pariwisata Riau. Propinsi Riau sebagai salah satu provinsi yang juga memiliki beberapa kawasan objek wisata yang dapat diunggulkan diberikan kewenangan untuk mengelola dan mengembangkan potensi wisata yang dimiliki tersebut. Propinsi Riau memiliki berbagai macam Kabupaten yang memiliki ketersedian objek wisata yang menarik. Salah satu kabupaten yang memiliki potensi dan daya tarik wisata yang dapat diunggulkan, adalah Kabupaten Kuantan Singingi.

Di bidang Pariwisata, Kabupaten Kuantan Singingi mempunyai potensi yang besar. Potensi wisata tersebut berupa budaya ataupun keindahan alam. Dari potensi wisata tersebut, yang sangat prospektif dikembangkan adalah jenis obyek wisata alam dan wisata budaya dengan atraksi-atraksi budaya lainnya. Salah satunya objek wisata yang dapat diunggulkan di Kabupaten Kuantan Singingi adalah objek wisata Danau Mesjid Koto Kari. Lokasi Danau Masjid Koto Kari berada di Kecamatan Kuantan Tengah, Kabupaten Kuantan Singingi, sekitar $3 \mathrm{~km}$ dari Kota Teluk Kuantan melalui jalan provinsi ke arah Sumatra Barat. Danau Masjid Koto Kari berukuran 200 x 800 m yang dikelilingi kebun karet masyarakat dan Koto Kenegerian Kari. Area di sekitar Danau Masjid Koto Kari merupakan hunian kawanan monyet (cigak, cingkuk dan koka). Di tempat ini, khususnya setiap Hari Raya Idhul Fitri, pengunjung juga bisa melihat lomba Pacu Jalur tingkat kabupaten.

Panorama saat matahari tenggelam di Danau Masjid Koto Kari ini kabarnya sangat indah. Keindahan alam di Danau Masjid Koto Kari sangat mempesona, apalagi kalau dikunjungi saat matahari hampir tenggelam.Danau Mesjid terletak sekitar $3 \mathrm{Km}$ dari Teluk Kuantan. Dari Teluk Kuantan dapat ditempuh dengan kendaraan pribadi maupun kendaraan umum menuju ke barat ke arah jalan Lubuk Jambi Kiliran Jao, dengan hitungan menit saja sudah sampai kita di simpang, belok ke kiri jalan ke 'Danau Mesjid' sejauh 300m dari simpang jalan raya. Disana dapat menikmati keindahan Danau Mesjid dengan sampan dayung serta fasilitas lainnya.

Jika melihat dari potensi yang dimiliki oleh Objek Wisata Danau Mesjid ini maka hal itu sesuai dengan peraturan Mentri Kebudayaan dan Pariwisata PM.37/UM.001/MKP/07 tentang kriteria dan keunggulan destinasi pariwisata sekurang-kurangnya meliputi: Ketersediaan semberdaya dan daya tarik wisata; Fasilitas pariwisata dan fasilitas umum; Aksesibilitas; Kesiapan dan keterlibatan masyarakat; Potensi pasar; Posisi strategi pariwisata dalam pembangunan daerah. Pembangunan pariwisata mempunyai peranan penting karena disamping sebagai penggerak perekonomian juga diharapkan meningkatkan kesempatan kerja dan peningkatan pendapatan masyarakat selain itu pariwisata juga merupakan salah satu bentuk pemenuhan kebutuhan masyarakat akan kepuasan terhadap hal-hal yang bersifat batiniah. Dalam rangka memanfaatkan peluang pariwisata yang secara prospektif dapat menguntungkan, maka diperlukan juga iklim usaha yang kondusif agar dapat menjamin berlangsungnya kegiatan pariwisata, serta membuka peluang investasi guna meningkatkan aktifitas pariwisata. Selanjutnya melalui pengelolaan berbagai potensi secara optimal diharapkan akan dapat menarik dunia usaha untuk melakukan kegiatan penanaman modal di Kabupaten Malang dapat dipastikan bahwa 
aktivitas ekonomi akan meningkat dan pada gilirannya akan mengangkat kesejahteraan masyarakat dampaknya akan berpengaruh sekali terhadap peningkatan pendapatan asli daerah.

Secara umum permasalahanpermasalahan yang sedang dihadapi pada masing-masing obyek wisata dalam pengembangannya memiliki kesamaan yakni sebagai berikut: 1). Sarana dan prasarana transportasi untuk menjangkau obyek wisata Danau Mesjid masih mengalami kesulitan terutama kondisi jalan yang rusak. 3). Kurangnya peran serta masyarakat dalam mengembangkan obyek Danau Mesjid. 4). Masih langkanya cinderamata khas di obyek wisata Danau Mesjid. 5). Obyek wisata Danau Mesjid belum dikembangkan dan masih alami. 6). Promosi tentang keunikan obyek wisata Danau Mesjid sangat terbatas. 7). Sarana dan prasarana penunjang atraksi wisata di Danau Mesjid masih terbatas. 8). Sarana dan prasarana penginapan di sekitar objek wisata Danau Mesjid terbatas.

Melihat dari permasalahan diatas maka sangat dibutuhkan strategi dari dinas terkait yaitu Dinas Pariwisata pemuda Dan Olahraga untuk dapat mengembangkan objek wisata Danau Mesjid dengan baik agar menjadi lebih dikenal oleh masyarakat. Upaya Dinas Pariwisata pemuda Dan Olahraga Seni Dan Budaya Kabupaten Kuantan Singingi dalam mengembangkan kawasan wisata Danau Mesjid hingga kini belum kunjung direalisasi. Cara yang dilakukan, mulai dari dikelola sendiri sampai mencari pihak ketiga yang hingga saat ini masih belum menunjukkan ada perkembangan yang signifikan. Melihat hal demikian maka sangat dibutuhkan strategi yang bagus dari Dinas Pariwisata pemuda Dan Olahraga Seni Dan Budaya dalam mengelola serta mengembangkan Danau Mesjid sehingga dapat menjadi wisata yang diandalkan di Kabupaten Kuantan Singingi.

Sebagai kerangka pemikiran di dalam penulisan perlu adanya landasan- landasan teori yang mendukung penelitian ini. Sesuai dengan uraian yang lainnya, berikut ini penulis akan mengemukakan beberapa teori yang ada hubungannya dengan masalah yang dibahas. Dalam bidang manajemen, definisi mengenai strategi cukup beragam dan bervariasi dari beberapa ahli dan pengarangnya. Gerry Johnson dan Kevan Scholes (2010: 22) mendefinisikan strategi sebagai arah dan cakupan jangka panjang organisasi untuk mendapatkan keunggulan melalui konfigurasi sumber daya alam dan lingkungan yang berubah untuk mencapai kebutuhan pasar dan memenuhi harapan pihak yang berkepentingan (stakeholder).

Menurut Pearce dan Robinson (2007:20) Strategi adalah 'rencana main' suatu perusahaan. Strategi mencerminkan

kesadaran perusahaan mengenai bagaimana, kapan dan di mana ia harus bersaing menghadapi lawan dan dengan maksud dan tujuan untuk apa. Sedangkan menurut Lynch seperti yang dikutip oleh Wibisono (2006: 50-51), strategi perusahaan merupakan pola atau rencana yang mengintegrasikan tujuan utama atau kebijakan perusahaan dengan rangkaian tindakan dalam sebuah pernyataan yang saling mengikat. Strategi perusahaan biasanya berkaitan dengan prinsip-prinsip secara umum untuk mencapai misi yang dicanangkan perusahaan, serta bagaimana perusahaan memilih jalur yang spesifik untuk mencapai misi tersebut.

Menurut Anthony dan Govindarajan (2005: 12) juga menambahkan bahwa perencanaan strategik merupakan suatu proses manajemen yang sistematis yang didefinisikan sebagai proses pengambilan keputusan atas program-program yang akan dilaksanakan oleh organisasi dan perkiraan sumber daya yang akan dialokasikan dalam setiap program selama beberapa tahun mendatang. Sedangkan menurut Morrisey (2005:45), strategi adalah proses untuk menentukan arah yang harus dituju oleh 
perusahaan agar misinya tercapai dan sebagai daya dorong yang akan membantu perusahaan dalam menentukan produk, jasa, dan pasarnya di masa depan. Dalam menjalankan aktifitas operasional setiap hari di perusahaan, para pemimpin dan manajer puncak selalu merasa bingung dalam memilih dan menentukan strategi yang tepat karena keadaan yang terus menerus berubah.

Igor Ansoff (2003: 15), mendefinisikan strategi sebagai proses manajemen, hubungan antara perusahaan dengan lingkungan, terdiri dari perencanaan strategik, perencanaan kapabilitas, dan manajemen perubahan. Sedangkan Arnoldo C. Hax dan Nicholas S. Manjluk (2003: 32), mendefinisikan strategi sebagai cara menuntun perusahaan pada sasaran utama pengembangan nilai korporasi, kapabilitas manajerial, tanggungjawab organisasi, dan sistem administrasi yang menghubungkan pengambilan keputusan strategik dan operasional pada seluruh tingkat hirarki, dan melewati seluruh lini bisnis dan fungsi otoritas perusahaan. John A. Pearce II dan Richard B. Robinson Jr., (2003: 21), Mendefinisikan strategi sebagai seperangkat keputusan dan tindakan yang menghasilkan formulasi dan implementasi dari rencana yang didesain untuk mencapai tujuan. Sedangkan Fred R. David (2005: 33) mendefinisikan strategi sebagai cara untuk mencapai tujuan jangka panjang. Strategi bisnis bisa berupa perluasan geografis, diversifikasi, akusisi, pengembangan produk, penetrasi pasar, rasionalisasi karyawan, divestasi, likuidasi dan joint venture. Sedangkan manajemen strategis dapat didefinisikan sebagai seni dan pengetahuan dalam merumuskan, mengimplementasikan, serta mengevaluasi keputusan-keputusan lintas fungsional yang memungkinkan suatu organisasi untuk mencapai tujuannya.

WF Glueck dan LR Jauch (2009: 41) mendefinisikan strategi sebagai rencana yang disatukan, luas dan berintegrasi yang menghubungkan keunggulan strategis perusahaan dengan tantangan lingkungan, yang dirancang untuk memastikan bahwa tujuan utama dari perusahaan dapat dicapai melalui pelaksanaan yang tepat oleh organisasi. Dari berbagai pengertian dan definisi mengenai strategi, secara umum dapat didefinisikan bahwa strategi itu adalah rencana tentang serangkaian manuver, yang mencakup seluruh elemen yang kasat mata maupun yang tak-kasat mata, untuk menjamin keberhasilan mencapai tujuan.

Menurut Oka A. Yoeti (2009 : 34) mengatakan bahwa wisatawan adalah seseorang yang melakukan perjalanan untuk sementara waktu tidak kurang selama 24 jam dan ia semata-semata sebagai konsumen bukan mencari nafkah atau bekerja tetap di tempat yang ia kunjungi. Menurut Happy Marpaung (2003 : 23) mengatakan bahwa PBB telah menetapkan batasan tourist (wisatawan) adalah para wisatawan sementara yang tinggal sekurang-kurangnya 24 jam di negara yang dikunjungi dan tujuan perjalanan dapat diklasifikasikan dari beberapa golongan yaitu, untuk bersenang-senang (rekreasi, berlibur, kesehatan, belajar, keagamaan dan olah raga), bisnis, keluarga, mission, rapat. Sementara itu excursionist adalah orang yang merupakan wisatawan sementara yang kurang dari 24 jam di negara atau daerah yang dikunjunginya termasuk para pelaku perjalanan melalui kapal-kapal pesiar.

Masih menurut Happy Marpaung (2003 : 36) mengatakan bahwa wisatawan adalah setiap orang yang bertempat tinggal di suatu negara tanpa memandang kewarganegaraannya berkunjung ke suatu tempat pada negara yang sama untuk jangka waktu lebih dri 24 jam yang tujuan perjalanannya dapat diklasifikasikan salah satu dari hal berikut: Memanfatkan waktu luang untuk berekreasi, liburan, kesehatan, pendidikan, keagamaan dan olah raga. Bisnis atau mengunjungi kaum keluarga. Instruksi presiden RI No. 9 Tahun 1996 
mengatakan tentang batasan "wisatawan adalah setiap orang yang melakukan perjalanan dan menetap untuk sementara di tempat lain selain tempat tinggalnya, untuk salah satu atau beberapa alasan selain mencari pekerjaan".

Menurut Oka A. Yoeti (2006: 114), Pariwisata diartikan sebagai perjalanan yang dilakukan berkali-kali atau berputar-putar dari suatu tempat ke tempat lain. Masih menurut Oka A. Yoeti (2006: 115), menyatakan bahwa Kepariwisataan adalah keseluruhan dari pada gejala-gejala yang ditimbulkan oleh perjalanan dan pendiaman orang-orang asing serta penyediaan tempat tinggal sementara asalkan pendiaman itu tidak tinggal menetap dan tidak memperoleh penghasilan dari aktifitas yang bersifat sementara. Menurut Witt dan Mountinho (2008: 324), Tidak dapat disangkal lagi bahwa pariwisata merupakan kegiatan terbesar saat ini dan telah berkembang secara cepat. I Gede Ardika (2007:3), memberikan pandangannya tentang unsur pariwisata yang terdiri dari beberapa komponen penting yakni, komponen akomodasi, atraksi, entertainment, dan fasilitas-fasilitas lain yang berupa biro-biro perjalanan umum. Pariwisata adalah perpindahan sementara yang dilakukan manusia dengan tujuan keluar dri pekerjaanpekerjaan rutin, keluar dari tempat kediamannya dengan melakukan aktifitas selama mereka tinggal di tempat yang dituju dan fasilitas dibuat untuk memenuhi kebutuhan mereka, menurut Happy Marpaung (2003 : 13).

Menurut Sihite, 2003 : 47) mengatakan bahwa Pariwisata sendiri diartikan sebagai suatu perjalanan yang dilakukan orang untuk sementara waktu yang diselenggarakan dari suatu tempat ketempat yang lain meninggalkan tempatnya semula dengan suatu perencanaan dan dengan maksud bukan untuk berusaha atau mencari nafkah di tempat yang dikunjunginya, tetapi sematamata untuk menikmati kegiatan pertamasyaan dan rekreasi atau untuk memenuhi keinginan yang beraneka ragam.

Dalam pengembangan suatu obyek wisata perlu diperhatikan tentang sarana dan prasarana, yang dimaksud sarana adalah semua bentuk perusahaan yang dapat memberikan pelayanan kepada wisatawan. Sedangkan yang dimaksud dengan prasarana (infrastructures) adalah semua fasilitas yang dapat memungkinkan proses perekonomian berjalan dengan lancar sedemikian rupa, sehingga dapat memudahkan manusia untuk dapat memenuhi kebutuhannya menurut Oka A Yoeti $(2005 ; 93)$.

\section{METODE}

Jenis penelitian deskriptif yang menjadi populasi dalam penelitian ini melibatkan Kepala Dinas dan karryawan yang ada di Dinas Pariwisata pemuda Dan Olahraga khususnya Divisi Pengembangan kepariwisataan dan wisatawan yang datang ke Objek Wisata Danau Mesjid di Kabupaten Kuantan Singingi. Data yang diperoleh dari hasil observasi dan wawancara dipilah-pilah dan diklasifikasikan menurut jenisnya dan kemudian dianalisis serta diolah dengan melakukan tabulasi terhadap data yang terkumpul, kemudian melakukan analisis mendapatkan gambaran dan disimpulkan secara deskriftif atau nyata yang sesuai dengan tujuan penelitian ini.

\section{HASIL}

Kabupaten Kuantan Singingi (Kuansing) adalah salah satu kabupaten di Provinsi Riau yang disebut pula dengan rantau Kuantan atau daerah perantauan orang-orang Minangkabau (Rantau nan Tigo Jurai). Kabupaten ini berada di bagian barat daya Propinsi Riau dan merupakan pemekaran dari Kabupaten Indragiri Hulu yang pada awalnya merupakan kecamatan, namun dimekarkan menjadi 2 kabupaten yaitu Kabupaten Indragiri Hulu dan Kabupaten Kuantan Singingi. Kabupaten ini merupakan gabungan dari 12 kecamatan, 
dengan batas utara yaitu Kabupaten Kampar dan Pelalawan, sebelah selatan berbatasan dengan propinsi Jambi, propinsi Sumatera Barat di sebelah barat dan Kabupaten Indragiri Hulu di sebelah timur. Danau Mesjid letaknya sangat srategis di kawasan penduduk dengan jarak lebih kurang 3,5 Km dari pusat kota Kabupaten Kuantan Singingi Teluk Kuantan. Maka sangat dibutuhkan strategi dari dinas terkait yaitu Dinas Pariwisata pemuda Dan Olahraga untuk dapat mengembangkan objek wisata Danau Mesjid dengan baik agar menjadi lebih dikenal oleh masyarakat.

Pada mulanya objek wisata Danau Mesjid ini dijadikan oleh masyarakat sebagai mata pencaharian yaitu mencari ikan lalu dijual ke pasar, ini dilakukan masyarakat setempat yang berada disekitar danau. Selanjutnya timbul keinginan dari pemuka masyarakat untuk mengembangkan Danau Mesjid ini sebagai tempat rekreasi atau tempat bersantai, maka pada tahun 1986, masyarakat setempat mulai melakukan gotong-royong yaitu dengan cara membersihkan danau secara bersama-sama, ini biasanya dilakukan pada hari libur terutama pada hari minggu. Dalam rangka usaha pengelolaan dan pengembangan danau direncanakan dalam dua tahap, tahap pertama merupakan pengelolaan kawasan danau yang diperkirakan hasilnya akan sangat sederhana diharapkan dapat dilanjutkan pengembngannya serta ditingkatkan kualitasnya dengan bantuan pembangunan pemda Kabupaten Kuantan Singingi. Melihat banyaknya peminat untuk memancing, yang pada umumnya bersama keluarga, maka alangkah baiknya jika pengunjung diberi fasilitas untuk berekreasi. Dengan mengadakan upaya penataan serta penambahan fasilitas-fasilitas lain, sehingga tercipta suatu objek wisata yang dikenal dengan Danau Mesjid.

Danau Mesjid berada dalam Wilayah Kenegrian Kari tepatnya di Desa Koto Kari. Secara geografis letaknya sangat srategis di kawasan penduduk dengan jarak lebih kurang
3,5 Km dari pusat kota Kabupaten Kuantan Singingi Teluk Kuantan dan danau ini merupakan tanah ulayat milik bersama warga masyarakat Kenegrian Kari, terhampar membujur panjan dari arah utara ke bahagian selatan dengan ukuran lebih kurang $600 \mathrm{x}$ $200 \mathrm{~m} \mathrm{(} 12 \mathrm{Ha}$ ). Apabila dilihat dari kepadatan penduduk, daerah ini belum begitu padat, namun demikian akan sangat mendukung bagi prospek pengembangan ke depan. Hal tersebut juga disebabkan oleh sarana dan prasarana untuk mencapai objek wisata tersebut mudah dijangkau. Diperkirakan Danau Mesjid ini akan menjadi induk dari kawasan wisata Danau Mesjid yang ditunjang oleh beberapa objek wisata yang berada disekitar danau selain itu kondisi objek wisata ini cukup memadai, dapat dilihat dari segi alam dan penghijauan yang ada. Hingga mampu memberi daya tarik bagi pengunjung dengan kesan suasananya yang sejuk, teduh, aman dan mempesona.

Dinas Pariwisata pemuda Dan Olahraga Seni dan Budaya Kabupaten Kuantan Singingi melalui evaluasi selalu mengadakan pengawasan terhadap perkembangan kepariwisataan di Kabupaten Kuantan Singingi . Dengan adanya evaluasi tersebut dapat diketahui bahwa berapa jumlah obyek wisata yang telah dikembangkan maupun yang belum dikembangkan. Berdasarkan hasil penelitian tersebut, Dinas Pariwisata Pemuda Dan Olahraga Kabupaten Kuantan Singingi mengadakan evaluasi terhadap kebijakankebijakan yang ada. Misalnya keadaan lokasi wisata yang kurang bersih sehingga menyebabkan wisatawan enggan berkunjung ke suatu obyek wisata, serta tingkat keamanan yang masih sangat kurang.

Peranan Dinas Pariwisata Pemuda Dan Olahraga Kabupaten Kuantan Singingi sangat diperlukan dalam upaya pengembangan obyek wisata. Hal ini sesuai dengan fungsi Dinas Pariwisata Pemuda Dan Olahraga antara lain : Pelaksanaan kewenangan di bidang pariwisata, seni dan budaya Kabupaten Kuantan Singingi, 
Perencanaan, pelaksanaan, pengawasan dan pengendalian serta evaluasi dan pelaporan penyelenggaraan di bidang pariwisata, seni dan budaya Kabupaten Kuantan Singingi, Pelaksanaan kebijakan operasional, pemberian bimbingan dan pembinaan, Pemberian perijinan di bidang pariwisata, seni dan budaya, Pengelolaan administrasi umum meliputi ketatausahaan, keuangan, kepegawaian, peralatan dan kelengkapan Dinas, Penyelenggaraan dan pengawasan standar pelayanan minimal yang wajib dilaksanakan dalam bidang pariwisata, dan pengembangan suatu obyek wisata yang dilakukan oleh Dinas Pariwisata pemuda Dan Olahraga dimaksudkan agar para wisatawan merasa nyaman dalam kegiatan berwisata. Kegiatan pengembangan obyek wisata hendaknya dapat menyediakan sarana dan prasarana yang diperlukan wisatawan. Karena pengembangan obyek wisata berkaitan dengan peningkatan mutu pelayanan kepada wisatawan.

Adapun strategi-strategi yang dilakukan oleh Dinas Pariwisata Pemuda Dan Olahraga Kabupaten Kuantan Singingi dalam memajukan Kawasan Wisata Danau Mesjid adalah:

\section{Meningkatan aktivitas promosi}

Promosi dan pemasaran pariwisata dimaksudkan untuk mengenalkan obyekobyek wisata yang dapat menarik minat wisatawan ke Kabupaten Kuantan Singingi terutama Objek Wisata Danau Mesjid. Melalui kegiatan promosi maka akan menambah wawasan bagi wisatawan terhadap obyek wisata yang ada. Disamping itu, promosi diharapkan sebagai upaya untuk lebih mengenalkan daerah tersebut ke dunia luar. Sehingga para wisatawan tertarik dan akhirnya mengunjungi obyek wisata yang dimaksud. Kegiatan promosi memberikan gambaran yang dapat menciptakan citra bagi daerah tujuan wisata yang bersangkutan. Menarik tidaknya suatu kegiatan atau materi promosi obyek/atraksi wisata tidak saja tergantung pada desain atau visualisasi dari bahan-bahan promosi yang diberikan. Namun juga pada tersampaikannya seluruh informasi yang dibutuhkan oleh calon wisatawan mengenai daerah tujuan yang akan dikunjunginya tersebut.

Promosi kepariwisataan yang ada harus diimbangi dengan bentuk-bentuk promosi sebagai pengenalan obyek-obyek wisata yang ada. Bentuk-bentuk promosi tersebut berupa aktivitas promosi dan pemasaran yang bertujuan untuk menarik minat wisatawan. Adapun aktivitas promosi dan pemasaran yang telah dilakukan oleh Dinas Pariwisata Pemuda Dan Olahraga seni Kabupaten Kuantan Singingi antara lain : Pameran pariwisata di Pekanbaru; Pameran Pekanbaru \& Riau Expo; Meja informasi/ Desk Information; Baliho, Event; Radio, Televisi. Dengan seringnya aktivittas promosi dilakukan maka akan membuat Kabupaten Kuantan Singingi terutama Objek Wisata Danau Mesjid lebih dikenal oleh wisatawan maka mereka akan memiliki minat yang tinggi untuk datang berkunjung. Promosi yang berkelanjutan akan membuat seseorang akan selalu ingat akan objek wisata yang dipromosikan begitu juga dengan promosi yang dilakukan Kabupaten Kuantan Singingi

\section{Melakukan Pembuatan Perda Tentang Pariwisata Kuantan Singingi} Pemerintah daerah harus segera membuat Peraturan Daerah (Perda) atau memperbaharuhi Perda yang telah dibuat yang bisa menjelaskan dan mengambarkan pariwisata Kuantan Singingi di masa depan. Perda tersebut harus bisa menyatukan pandangan dan pemahaman bagaimana rencana pengembangan pariwisata di Kabupaten Kuantan Singingi, sehingga memudahkan setiap daerah menyusun kebijakan pengembangan pariwisata. Dengan terbentuknya pemahaman yang sama dalam mengembangkan pariwisata di masing-masing daerah tingkat II, diharapkan bisa mempercepat pengembangan pariwisata di Kuantan Singingi. Untuk membuat Perda 
pariwisata tersebut dibutuhkan kerjasama yang baik antara ASITA, PHRI, LSM, dan DPRD sehingga perda yang dihasilkan betulbetul mencerminkan keinginan masyarakat.

Perda yang dihasilkan tidak mengabaikan filosofi dan falsafah hidup masyarakat serta bersifat komprehensif dalam upaya menciptakan cara untuk pengembangan dan pembangunan pariwisata yang berbasis masyarakat. Baik dilihat dari aspek kriteria, konsep model (karakteristik daerah) maupun pedoman, mencakup: produk, market, pedoman, pelatihan SDM dan perencanaan bisnis (statement operational procedure) dalam upaya peningkatan peran serta pariwisata dalam meningkatkan pendapatan masyarakat.

\section{Pengembangan Sarana dan Prasarana}

Pengembangan Sarana dan Prasarana Danau Mesjid sebagai Daya Tarik Objek Wisata yang diunggulkan menitik beratkan pada skala prioritas, dimana pembangunannya masih dalam proses perbaikan. Adapun kinerja pengembangan sarana dan prasarana Danau Mesjid sebagai Daya Tarik Objek Wisata ditekankan pada aspek penngembangan aksebilitas dan infrastruktur. Danau Mesjid sebagai Daya Tarik Objek Wisata sangat berpotensi dijadikan DTW (daerah tujuan wisata) bagi para wisatawan.

Pembangunan merupakan bagian pengembangan, secara garis besar pada tahap operasional terdapat pekerjaan yang mesti dicermati yakni penanganan pengunjung dan pemeliharaan fasilitas termasuk lingkungan sekitarnya. Dampak dari kegaitan ini adalah memberikan kenyamanan pada wisatawan serta kelanjutannya untuk waktu yang lama dan memberikan keuntungan bagi seluruh masyarakat. Selain itu juga terdapat peran masyarakat sebagai sektor pendukung yang masih perlu dikembangkan, sehingga perlu program-program yang bisa mengajak masyarakat bisa merasakan menjadi bagian dari Objek Danau Mesjid.

\section{Membangun Fasilitas Penunjang}

Fasilitas merupakan sarana dan prasarana dalam sebuah objek wisata yang terintegrasi antara satu dan yang lainnya yang bertujuan untuk memenuhi kebutuhan wisatawan selama berada diobjek wisata harus memperhatikan keberadaan fasilitasfasilitas yang ada sehingga pengunjung menjadi puas. Staff Dinas Pariwisata Pemuda dan Olahraga terhadap strategi yang dilakukan dalam memajukan Kawasan Wisata Danau Mesjid dapat dilihat bahwa rata-rata staff menilai Baik (B) yaitu 6 orang dengan persentase $60 \%$. Mereka menilai demikian dikarenakan beberapa alasan yaitu: Strategi tersebut dinilai sudah cukup baik untuk memajukan pariwisata di Kabupaten Kuantan Singingi terutama memajukan Objek Wisata Danau mesjid. Strategi sudah masuk di dalam rencana kerja Dinas Pariwisata.

\section{Persepsi Wisatawan Terhadap Objek Wisata Danau Mesjid Di Kabupaten Kuantan Singingi}

Untuk membangun suatu Kawasan Objek Wisata, terlebih dahulu perlu diketahui potensi-potensi yang ada diareal yang akan dibangun tersebut. Sesuai dengan kondisi fisiknya, Danau Mesjid mempunyai potensi yang memadai untuk dijadikan Daerah Tujuan Wisata. Sejak awal didirikan Objek Wisata Danau Mesjid, berbagai upaya dan kebijakan telah dilakukan untuk menjadi kawasan yang luasnya sekitar $12 \mathrm{Ha}$. Ini dapat dijadikan sebagai suatu kawasan Objek Wisata. Secara bertahap baik dana serta kemampuan yang terbatas, perkembangan terus dilakukan mulai dari pembersihan danau, pembuatan jalan menuju danau, serta penanaman pohon-pohon lindung untuk keindahan serta tanaman bunga untuk keindahan.

Melihat pengunjung yang 276ltern ke objek ini umumnya membawa keluarga, maka diadakan usaha beberapa 276lternative rencana yang di maksudkan untuk 
meningkatkan mutu objek, dengan mengadakan Pacu Jalur Mini pada Objek Wisata Danau Mesjid tersebut. Sampai saat sekarang Objek Wisata Danau Mesjid sudah mampu menciptakan suasana aman, tenang dan teduh dengan pepohonan yang rindang memberikan kesan yang menyenangkan bagi pengunjung.

Berikut ini penulis uraikan beberapa tanggapan wisatawan terhadap Kawasan Wisata Danau Mesjid di Kabupaten Kuantan Singingi.

\section{Penataan Kawasan Objek Wisata Danau Mesjid}

Penataan yang baik oleh Dinas Pariwisata pemuda Dan Olahraga akan menyebabkan Kawasan ini lebih dikenal oleh masyarakat luas sehingga akan mendatangkan wisatawan ke Kabupaten Kuantan Singingi. Dengan Penataan yang baik dan terencana maka Kawasan Objek Wisata Danau Mesjid akan menjadi lebih diminati oleh pengunjung sehingga Pendapatan Asli Daerah (PAD) akan meningkat demikian juga dengan pendapatan masyarakat tempatan. Bahwa ada beberapa orang wisatawan yang menilai penataan Objek Wisata Danau Mesjid Tidak Baik (TB) yaitu 10 orang dengan persentase adalah $20 \%$. Alasan mereka menjawab hal demikian adalah dikarenakan: Masih belum baiknya penataan Kawasan Objek Wisata Danau Mesjid yang dapat dilihat dari Anjungan nya yang masih seadanya. Objek pendukung untuk Kawasan ini belum tertata dengan baik sehingga terkesan apa adanya.

\section{Event/ atraksi Kawasan Objek Wisata Danau Mesjid}

Pemerintah Kabupaten Kuantan Singingi melalui Dinas Pariwisata pemuda Dan Olahraga berusaha menyajikan event/atraksi yang mendukung di Kawasan Wisata Danau Mesjid agar wisatawan dapat melihat sekaligus menikmati hiburan yang ada di Kawasan Danau Mesjid. Adanya event/atraksi yang dikemas dengan baik oleh Dinas Pariwisata pemuda Dan Olahraga merupakan modal dasar untuk menarik minat para wisatawan. Wisatawan rata-rata menilai bahwa Kawasan Objek Wisata Danau Mesjid Baik (B) yakni 30 orang dengan persentase adalah $60 \%$. Para wisatawan menilai demikian dengan 277las an bahwa: Dimasukkannya tentang kebudayaan lokal di dalam event/ atraksi tersebut sehingga hal ini menjadi daya tarik bagi wisatawan. Setiap even/ atraksi yang dibuat oleh pengelola melalui Dinas Pariwisata pemuda Dan Olahraga tetap berakar pada budaya lokal. Tetapi dapat dilihat juga masih ada wisatawan yang menjawab Tidak Baik (TB) yaitu 7 orang dengan persentase $14 \%$. Hal ini dikarenakan beberapa hal yaitu: Event/ atraksi yang dilaksanakan tersebut masih kurang optimal sehingga terkesan apa adanya. Event/ atraksi yang dilaksanakan tidak dikemas dengan baik sehingga kurang menarik bagi wisatawan.

\section{Fasilitas Kawasan Objek Wisata Danau Mesjid}

Fasilitas yang mendukung Kawasan Objek Wisata Danau Mesjid merupakan hal yang paling utama harus diperhatikan oleh Dinas Pariwisata pemuda Dan Olahraga Kabupaten Kuantan Singingi. Fasilitas yang memadai akan membuat objek wisata tersebut akan ramai dikunjungi, seperti adanya jalan yang baik menuju ke sana di samping fasilitas lainnya. Semua ini bertujuan untuk menarik minat wisatawan berkunjung ke tempat tersebut. rata-rata wisatawan menilai fasilitas di Kawasan Wisata Danau Mesjid adalah Tidak Baik (TB) yaitu 9 orang dengan persentase $18 \%$. Alasan mereka menjawab hal tersebut adalah: Jalan menuju ke kawasan objek wisata Danau Mesjid masih belum diaspal dengan baik sehingga wisatawan kurang nyaman dengan kondisi ini. Tidak adanya penginapan yang dibangun oleh swasta maupun yang disediakan oleh Pemda di sekitar kawasan Objek Wisata Danau Mesjid sehingga wisatawan terpaksa menginap di penginapan yang ada di pusat kota. 
Keamanan Kawasan Objek Wisata Danau Mesjid

Faktor keamanan merupakan hal yang sangat dibutuhkan oleh wisatawan saat berada di Kabupaten Kuantan Singingi maupun di Kawasan Wisata Danau Mesjid. Rasa aman yang tercipta akan membuat wisatawan merasa betah dan nyaman. Rata-rata wisatawan menilai keamanan di Kawasan Wisata Danau Mesjid termasuk ke dalam hal Baik (B) yaitu 29 orang dengan persentase $58 \%$. Mereka menjawab hal demikian dikarenakan beberapa alasan: Mereka tidak pernah mengalami hal-hal yang merugikan mereka seperti penodongan, kecopetan dan lain sebagainya selama mereka berada di kawasan tersebut. Adanya sikap masyarakat yang sangat menghargai wisatawan yang datang. Di bidang Pariwisata, Kabupaten Kuantan Singingi mempunyai potensi yang besar. Potensi wisata tersebut berupa budaya ataupun keindahan alam. Dari potensi wisata tersebut, yang sangat prospektif dikembangkan adalah jenis obyek wisata alam dan wisata budaya dengan atraksi-atraksi budaya lainnya. Salah satu diantaranya objek wisata yang ada di Kabupaten Kuantan Singingi adalah: Air Terjun Guruh Gemurai yang terletak di Kasang Kecamatan Kuantan Mudik; Air Terjun 7 Tingkat Batang Koban yang terletak di Lubuk Ambacang Kecamatan Hulu Kuantan; Air Terjun Pati Soni yang terletak di Desa Cengar Kecamatan Kuantan Mudik; Sumber Air Panas yang terletak di Sungai Pinang Kecamatan Hulu Kuantan; Danau Mesjid yang terletak di Koto Kari Kecamatan Kuantan Tengah; dan desa Wisata yang terletak di Koto Sentajo. Diantara objek wisata yang ada di Kuantan Singngi objek wisata yang sering penulis kunjungi adalah Objek Wisata Danau Mesjid yang terletak di Koto Kari Kecamatan Kuantan Tengah.

\section{PEMBAHASAN}

Usaha pariwisata nasional memegang peranan penting dalam meningkatkan devisa negara menciptakan lapangan pekerjaan, mempererat persahabatan antara banqsa, karena pariwisata mempertemukan antara satu negara dengan negara lainnya. Apalagi Indonesia berada pada posisi silang antara dua benua dan dua samudera. Potensi pariwisata Indonesia sangatlah besar baik dari potensi alam, hutan, kebudayaan maupun fauna dan flora. Lebih jauh lagi peran dan fungsi usaha pariwisata nasional mempunyai posisi yang strategis dalam rangka memulihkan perekonomian nasional secara tepat dan akurat dan sekaligus memperkokoh persatuan dan kesatuan bangsa dalam rangka perwujudan wawasan nusantara serta peningkatan ketahanan nasional, dalam rangka membangun dan mengembangkan usaha pariwisata nasional, maka salah satu aspek adalah aspek hukum.

Sebab tanpa adanya perangkat hukum nasional yang menjadi landasan dan arah kebijakan pembangunan bidang pariwisata, maka tidak mungkin dapat terwujud suatu kondisi kehidupan usaha pariwisata yang efektif dan mampu bersaing dengan pengusaha asing khususnya dalam era globalisasi saat ini. Berbagai produk hukum dan kebijakan yang diambil pemerintah dalam bidang pariwisata selama ini dirasakan belum dapat memberikan suatu iklim yang kondusif untuk mendukung pertumbuhan dan perkembangan usaha pariwisata nasional. Dalam melakukan pengembangan daya tarik Kawasan Objek Wisata Danau Mesjid, Dinas Pariwisata Pemuda Dan Olahraga Kabupaten Taluk Kuantan memiliki hambatan-hambatan yang cukup berarti dikarenakan mereka tidak mampu bekerja dengan sendiri tanpa bantuan dari pihak luar seperti investor. Ada beberapa faktor yang merupakan hambatan-hambatan Dinas Pariwisata Pemuda Dan Olahraga dalam mengembangkan Kawasan Objek Wisata Danau Mesjid yaitu:

\section{Pengelolaan yang belum Memadai}

Dinas Pariwisata Pemuda Dan Olahraga sebagai pengelola saat ini masih belum cukup mampu mengelola kawasan wisata Danau Mesjid dengan baik sehingga diperlukan pengelolaan yang lebih 
profesional. Upaya Pemerintah Kabupaten Kuantan Singingi dalam mengembangkan kawasan wisata Danau Mesjid hingga kini belum kunjung direalisasi. Berbagai macam cara yang dilakukan, mulai dari dikelola sendiri sampai mencari pihak ketiga yang hingga saat ini keinginan mengembangkan Danau Mesjid masih belum menunjukkan ada perkembangan yang signifikan.

\section{Masih Kurangnya Promosi yang} dilakukan

Pemasaran Objek Wisata Danau Mesjid ini 279ocu melalui event Pacu Jalur yang diadakan setiap tahunnya di Teluk Kuantan, informasi dan promosi menjadi kekuatan tersendiri yang keberadaannya tidak diabaikan. Informasi dan promosi diperlukan sebagai 279 ocus 279 penting dalam pemasaran pariwisata saat ini sudah tesedia berbagai informasi dan promosi., baik dalam bentuk media cetak, audio, dan visual, melalui brosur, booklet, pertujukan budaya, pameran dan lain-lainya. Hasil wawancara menunjukkan bahwa penyebaran informasi dan promosi wisata lewat mulut ke mulut masih efektif dilakukan dalam usaha mempromosikan keberadaan Objek Wisata di Kuantan Singingi keluar daerah. Hal ini dapat dilakukan oleh warga Kuantan Singingi di perantauan baik pekerja, mahasiswa atau lainnya.

\section{Pengembangan masih fokus pada aspek fisik saja}

Pengembangan dan pengelolaan kawasan Danau Mesjid masih 279ocus hanya pada pengembangan aspek fisik saja, seperti hanya mengembangkan karena potensi alamnya. Fisik yang harus dikembangkan yaitu segala fasilitas baik sarana dan prasarananya sehingga objek wisata Danau Mesjid dapat lebih baik lagi dan pengunjung akan bertambah banyak untuk datang kesana.

\section{Kurangnya Dana yang tersedia}

Besarnya dana yang digunakan untuk pengembangan Kawasan Objek Wisata Danau Mesjid merupakan hal sangat penting dalam pengembangan kawasan tersebut. Jumlah dana yang tersedia merupakan salah satu faktor penting yang mempengaruhi faktor pengembangan, promosi, sehingga Pemerintah Daerah melalui Dinas Pariwisata Pemuda Dan Olahraga harus memperkirakan dana untuk melakukan pengembangan. Dalam pengembangan Kawasan Objek Wisata Danau Mesjid ini memang memerlukan dana yang cukup banyak sehingga Pemerintah Daerah harus mencari sumber dana dari pihak luar atau pihak swasta.

\section{Masih Kurangnya Minat Investor}

Dalam melakukan pengembangan suatu daya tarik wisata termasuk Kawasan Objek Wisata Danau Mesjid tidaklah mudah mengingat akan kebutuhan dana yang cukup besar. Maka untuk menanggulangi hal ini Pemerintah daerah Kabupaten Kuantan Singingi melalui Dinas Pariwisata Pemuda Dan Olahraga berusaha untuk menghimbau investor-investor agar dapat turut serta menanamkan modalnya di bidang ini. Akan tetapi minat para investor untuk menanamkan modalnya guna mengembangkan Kawasan Objek Wisata Danau Mesjid masih kurang. Kurangnya minat investor dikarenakan beberapa hal: Hal ini dikarenakan mereka takut jika modal yang telah mereka tanamkan tidak dapat kembali lagi atau mengalami kerugian. Mereka melihat selama ini orangorang yang melakukan kunjungan ke Kabupaten Kuantan Singingi untuk menikmati objek wisata yang ada masih sangat kurang. Aspek berkembangnya Kawasan Objek Wisata Danau Mesjid belum dapat memotivasi investor karena kawasan tersebut masih belum banyak pengunjungnya.

Jadi dengan masih kurangnya minat investor-investor terhadap Kawasan Objek Wisata Danau Mesjid di Kabupaten Kuantan Singingi akan dapat menghambat berkembangnya kawasan tersebut sehingga pengembangan akan berjalan lambat. Berikut ini penulis sajikan tanggapan staff Dinas Pariwisata Pemuda dan Olahraga terhadap hambatan-hambatan mengembangkan Objek Wisata Danau Mesjid menjadi wisata 
unggulan di Kabupaten Kuantan Singingi.

\section{SIMPULAN}

Kesimpulannya adalah Dinas Pariwisata Pemuda Dan Olahraga Kabupaten Kuantan Singingi sebagai Pengelola telah membuat langkah kerja dalam mengembangkan Objek Wisata Danau Mesjid. Mereka berusaha menjalankan strategi-strategi yang di anggap mampu untuk mengembangkan Objek Wisata Danau Mesjid. Strategi-strategi yang dilakukan oleh Dinas Pariwisata Pemuda Dan Olahraga tersebut seperti: Meningkatan aktivitas promosi, Melakukan Pembuatan Perda Tentang Pariwisata Kuantan Singingi, Pengembangan Sarana Dan Prasarana, Membangun Fasilitas Penunjang, Objek wisata Danau Mesjid Koto Kari memiliki potensi objek yang cukup memadai baik dari sarana maupun prasarana pendukungnya. Potensi ini didukung oleh keadaan alam.

\section{DAFTAR RUJUKAN}

Arnoldo C. Hax dan Nicholas S. Manjluk. 2003. The Strategy Process and Concept, Gramedia Pustaka Utama. Jakarta.

Badan Pusat Statistik. 2013, Kabupaten Kuantan Singingi

Bryden, M John. 2003. Pariwisata Dalam Ekonomi. Kanisius. Yogyakarta

Dinas Pariwisata pemuda Dan Olahraga Seni Dan Budaya Kabupaten Kuansing. 2013. Brosur-brosur.

Ditjen PHPA.2003. Strategi Pengembangan

Produk Dan Promosi Ekowisata, Jakarta

Fandeli. 2005. Pengembangan Daya Tarik Wisata. Pustaka Sinar Harapan. Jakarta.

Fred R. David. 2005. Strategic Management: Concepts and Cases, Gramedia Pustaka Utama, Jakarta.

Garis-garis Besar Haluan Negara Republik Indonesia (GBHN). 2003

Gerry Johnson dan Kevan Scholes. 2010. Exploring Corporate Strategy, Gramedia, Jakarta.
Happy Marpaung. 2003. Gejala Pariwisata. Alfabetha. Bandung.

Http://www.kepariwisataankuantansingingi.c $\mathrm{om} / \mathrm{read} / 20013 / 04 / 04 / 68157 / 55 / 9 / D a$ nau-Mesjid-koto-Kari 2013-html

Igor Ansoff. 2003. Implanting Strategic Management, Prentice Hall, Gramedia Pustaka Utama, Jakarta.

I Gede Ardika, 2003, Penyelenggaraan Operasi Perjalanan Wisata, Grasindo, Jakarta.

Instruksi Presiden. 2006. No. 9. Republik Indonesia

John A. Pearce II dan Richard B. Robinson Jr. 2003. Strategic Management, formulation, implementation and control, Irwin McGraw-Hill, Gramedia Pustaka Utama, Jakarta.

Kaelany H D. 2003, Pengetahuan Kepariwisatan, Alfabetha, Bandung.

Ketetapan MPR No.II/MPR/2003

Ma. Desky, 2003, Manajemen Perjalanan Wisata, Adicita, Yogyakarta

Oka A. Yoeti. 2006. Ilmu Pariwisata Sebuah Pengantar Sederhana. Jakarta. PT. Pradnya Paramita.

Sumadi Suryabrata. 2003 Metodologi Penelitian, Rajawali Pers, Jakarta.

Sihite. 2003, Perjalanan Wisata. Pustaka Sinar Harapan, Jakarta

Spillanne, James J. 2004. Ekonomi Pariwisata. Sejarah dan prospeknya

Soekadijo, R.S. 2006. Anatomi Pariwisata. Jakarta. Gramedia.

Tourism, Art and Culture Office, 2011, Obyek dan Daya Tarik Wisata, Dinas Pariwisata pemuda Dan Olahraga Seni Dan Budaya, Pekanbaru.

Tontje Tnunay, 2008, Kegiatan Produk Pariwisata, Pradnya Paramita, Jakarta

Witt \& Moutinho. 2008, Pemasaran Pariwisata, Pradnya Paramita, Jakarta

WF Glueck dan LR Jauch. 2009, Manajemen strategis dan kebijakan perusahaan, Pustaka Sinar Harapan, Jakarta. 